\title{
Karakter Kewargaan Multikultural Berbasis Nilai Moral di Sekolah Menengah Atas Negeri 2 Kabupaten Sorong
}

\author{
Ihsan 1 \\ ${ }^{1}$ Pendidikan Pancasila dan Kewarganegaraan, Universitas Pendidikan Muhammadiyah Sorong, Email: ahmadmihsan0@gmail.com
}

\begin{tabular}{l} 
INFO ARTIKEL \\
\hline Riwayat Artikel: \\
Diterima: $\quad 21-$ \\
Februari-2019 \\
Disetujui: 10-Maret- \\
2019 \\
\hline
\end{tabular}

\section{Kata Kunci:}

karakter

kewargaan

multikultural

nilai

moral

\begin{abstract}
ABSTRAK
Abstrak: Tiap warga negera memiliki karakter yang berbeda-beda, adanya perbedaan dapat menyebabkan konflik. Konflik bisa dicegah apabila karakter nilai moral dibina dengan baik. Penelitian ini bertujuan yakni mengidentifikasi karakter kewargaan multikultural yang berbasis nilai Moral di SMA Negeri 2 Kabupaten Sorong dan kebutuhan masyarakat Papua pada Siswa yang berada di SMA Negeri 2 Kabupaten Sorong. Metode penelitian yang digunakan dalam penelitian ini adalah research and development. Subyek penelitian guru, siswa, dan kepala sekolah, metode pengumpulan data menggunaakan studi literature, peer discussion dan focus group discussion, analisis data menggunakan dilakukan secara deskriptif dengan pendekatan data kualitatif. Hasil penelitian menemukan sekolah merupakan pihak yang mempunyai kewenangan dalam mendidik dan membina Siswa sehingga dapat terbentuk karakter kewargaan yang berbasis nilai moral. Siswa merupakan calon pendidik masa depan dan harus memiliki model pembinaan berbasis nilai moral dalam lingkungan Siswa di sekolah SMA Negeri 2 Kabupaten Sorong. Kebutuhan karakter kewargaan berbasis nilai moral sekolah masih sangat diperlukan demi mewujudkan kepribadian anak masa depan yang lebih berkualitas. Jadi pembinaan karakter berbasis nilai moral Siswa papua penting dilakukan.
\end{abstract}

\begin{abstract}
Every citizen has different characters; differences can cause conflict. Conflict can prevent if the attitude of moral values was fostered correctly. This study aims to identify the character of Moral-based multicultural citizenship in SMA Negeri 1 Sorong and the needs of Papuan people in Students in SMA Negeri 1 Sorong. The research method used in this study is research and development. The research subjects were teachers, students, and principals, data collection methods used literature studies, peer discussions, and focus group discussions, using data analysis was carried out descriptively with a qualitative data approach. The results of the study found that the school is a party that has the authority to educate and foster students so that the character of citizenship based on moral values can be formed. Students are prospective future educators and must have an ethical value-based guidance model in the Student environment at SMA Negeri 1 Sorong. The character needs of citizenship based on school moral values are still very much needed to realize the personality of a better quality future child. So character building based on ethical values of Papuan students is essential.
\end{abstract}

\section{A. LATAR BELAKANG}

Secara historis dan sosio-kultural pembangunan bangsa dan pembangunan karakter (nation and character building) merupakan komitmen nasional yang telah lama tumbuh dan berkembang dalam kehidupan masyarakat, bangsa dan negara Indonesia. Namun demikian, ternyata dalam praktis politik pembangunan dan pendidikan keseriusan perhatian terhadap pembangunan karakter bangsa belum terjaga dengan baik, sehingga hasilnya belum optimal. Fenomena keseharian menunjukkan perilaku masyarakat belum sejalan dengan karakter bangsa yang dijiwai oleh Falsafah Pancasila, sehingga sekolah, mengambil langkah dengan memberi materi PKn dengan kurikulum, yang didalamnya meliputi: Pendidikan Pancasila dan Kewarganegaraan. Berbagai gejolak dalam masyarakat kita pada beberapa tahun terakhir, sangat memprihatinkan. Munculnya perilaku buruk yang ditandai kondisi kehidupan sosial budaya yang berubah sedemikian drastis dan fantastis. Bangsa Indonesia yang sebelumnya dikenal penyabar, ramah, penuh sopan santun dan pandai berbasa-basi sekonyong-konyong menjadi pemarah, suka mencaci, pendendam, perang antarkampung dan suku dengan tingkat kekejaman yang sangat tidak manusiawi membuat rasa keprihatinan yang mendalam.

Penelitian ini didorong oleh penelitian [1] yang memperlihatkan arti penting gagasan masyarakat multikultural penting diwujudkan melalui proses pendidikan kewarganegaraan di Sekolah. Hal ini juga sejalan dengan penelitian [2] mengidentifikasi bahwa kompetensi kewargaan multikultural dapat dikembangkan melalui beragam kajian pembelajaran seperti social studies yang di dalamnya memuat topik pendidikan kewarganegaraan seperti di Amerika Serikat. Dengan civic multicultural competence diharapkan para 
dosen mampu menyiapkan Siswa menghadapi kehidupan masyarakat global yaitu masyarakat multikultural. Nilai-nilai pendidikan multikultural merupakan Keterbukaan tersebut dari segi penerimaan Siswanya yang dari berbagai macam latar belakang, di samping juga terbuka dalam menjalin hubungan kerjasama dalam bidang keilmuan dengan berbagai pihak tanpa harus membatasi diri hanya pada pihak yang beridentitaskan Islam saja [3].

Di era reformasi, menghidupkan kembali semangat ber-Pancasila dalam kehidupan bermasyarakat dan bernegara secara pasif disosialisasikan oleh MPR RI. Kebijakan yang dikenal ialah dengan Kenegaraan", meliputi Pancasila, UUD Negara Kesatuan Republik Indonesia dan Bhinneka Tunggal Ika. Nilai Moral ini kemudian dijadikan materi pokok dalam nomenklatur Pendidikan Kewarganegaraan seba-gaimana disebut dalam [4].

Karakter kewargaan setiap bangsa memiliki perbedaan, perbedaan itu dipengaruhi oleh lingkungan, alam, masyarakat, budaya, keluarga serta ekonomi. Kajian karakter kewargaan sebelumnya sudah ada yang menuliskan salah satunya adalah penelitian sebelumnya menemukan bahwa perilaku kewargaan dapat dipengaruhi oleh iklim organisasi yang ada di masyarakat, namun iklim organisasi tidak berpengaruh terhadap stres kerja[5]. Demikian juga peneliti lain menemukan bahwa pembentukan budaya kewargaan pada masyarakat khusus sebagai situs kewarganegaraan, tampak pada tiga bidang; bidang pendidikan, bidang sosial, dan bidang politik. Pada bidang pendidikan, sebaga tempat melakukan penanaman nilai-nilai keagamaan dan nilai-nilai kebangsaan, pada bidang sosial, lebih tampak pada program-program pemberdayaan masyarakat dan bidang politik, secara institusional kedua lembaga tersebut tidak berafiliasi pada partai politik tertentu namun berfungsi sebagai partisipan dalam beberapa partai politik yang berbeda[6]. Terkait dengan temuan-temuan tersebut, bahwa karakter kerwargaan seseorang tidak mesti dipengaruhi oleh iklim organisasi, bidang pendidikan, social dan politik akan tetapi dapat dipengaruhi oleh nilai-nilai local yang berkembang di masyarakat teruatama masyarakat adat.

Dengan demikian penelitian tentang karakter kewargaan multicultural berbasis nilai moral belum banyak yang menulisnya, oleh karena itu dalam artikel ini akan menjabarkan apa saja yang belum ditemukan oleh penelitian terdahulu. Karakter kewargaan multicultural berbasis nilai moral merupakan model pembinaan, pengalaman dan kebutuhan praktis oleh guru kepada siswa untuk mewujudkan nilai moral sebagai unsur pembentuk karakter. Pembentukan karakter kewargaan multikultural dipengaruhi oleh adanya penguatan integrasi nilai-nilai Islam dan kebangsaan ke dalam wajah multikultural pendidikan
Islam Indonesia modern perlu dielaborasi lebih lanjut[7]. Sementara nilai moral merupakan karakter baik dan buruk perilaku seseorang, hasil temuan riset menunjukkan bahwa penanaman nilai-nilai dan moral agama untuk anak-anak berkisar pada aktivitas kehidupan sehari-hari. Semakin cepat nilai moral ditanamkan kepada anak seperti meletakkan dasardasar iman, kepribadian atau karakter yang praktek terpuji dan kebaktian, dalam mengimplementasikannya disesuaikan dengan kemampuan anak[8].

Hasil observasi di SMA Negeri 2 Kabupaten Sorong ditemukan bahwa sekolah tersebut termasuk sekolah favorit, unggul dan berprestasi pada lingkup wilayah Kabupaten Sorong. Disamping itu sekolah SMA Negeri 1 Sorong tergolong sekolah yang multicultural karena disekolah tersebut ada banyak perbedaan budaya, etnis, agama dan suku. Kemultilkultural muncul karena terdapat berbagai etnis, budaya, agama dan suku yang tumbuh. Hasil penutursn guru-guru menyampaikan ada $80 \%$ beragama Kristen, $15 \%$ beragama Islam dan $5 \%$ agama Hindu, Budha dan Konghuchu.

Berbagai perbedaan etnis, budaya, agama dan suku merupakan bukti kemultikulturalan Indonesia. Kemultikulturalan tersebut perlu dibangun melalui penanaman nilai moral pada sekolah sehingga nilai moral anak-anak tetap terbina, tumbuh dan berkembang si melalui pendidikan. Hasil penelitian menunjukkan bahwa multikulturalisme terbentuk karena segenap civitas akademika dalam hal ini pendidik dan siswa memiliki kemampuan dalam mengadaptasikan dirinya pada lingkungannya yang didalamnya terdapat berbagai budaya, pemahaman agama, daerah yang berbeda[9]. Multikultural sebagai sebuah konsep dimana sebuah komunitas dalam konteks kebangsan dapat mengakui keberagaman, perbedaan dan kemajemukan budaya, baik ras, suku, etnis maupun agama. Pendidikan multikultural memberikan pemahaman bahwa sebuah bangsa yang plural dan majemuk adalah bangsa yang dipenuhi dengan budaya-budaya yang beragam (multikultural)[10].

Penelitian ini dalam jangka panjang bertujuan untuk mengembangkan sejumlah komponen kompetensi kewarganegaraan untuk menjadikan nilai moral dan kekayaan ajaran warganegara dengan cara bertahan dengan pengutan karakter kewargaan generasi penerus bangsa di Abad ke-21. Secara khusus, tujuan penelitian ini adalah menggunakan komponen kompetensi kewarga-negaraan sebagai cara mengukur keberhasilan penanaman pembinaan kewargaan multikultural dengan menggunakan nilai moral dalam setiap dokumen yang menjadi dasar kehidupan bersama masyarakat Indonesia yang beranekaragam untuk membumikan keindonesiaan dalam proses pembelajaran. Untuk mencapai tujuan tersebut, penelitian ini menggunakan langkah-langkah penelitian menganalisis karakter kewargaan dalam mengembangkan kompetensi 
kewarganegaraan sebagai cara mengukur keberhasilan penanaman nilai moral masyarakat pada umumnya, khususnya Siswa SMA Negeri 2 Kabupaten Sorong.

Secara teknis ada dua pembentuk karakter nilai moral anak yaitu pertama, mengidentifikasi karakter kewargaan yang menjadi dasar kehidupan bersama masyarakat multikultur Indonesia dan menjadi pondasi kehidupan masyarakat. Kedua, menyusun model pengembangan komponen kompetensi kewarganegaraan untuk menjadikan nilai moral yang bermakna dan penting dalam pembentukan warga negara yang berkepribadian Indonesia. Dengan demikian, tujuan dalam artikel ilmiah ini yakni menguraikan dan mengidentifikasi karakter kewargaan multikultural yang berbasis nilai moral, identifikasi menggunakan komponen kompetensi kewarga-negaraan seperti sikap disiplin, kerja keras, tanggungjawab, saling menghargai dan menghormati. Kebutuhan masyarakat papua dalam membentuk karakter multicultural berbasis nilai moral berupa memberikan pendidikan yang lebih dan pembinaan yang inklusif.

\section{B. METODE PENELITIAN}

\section{Metode Penelitian yang Digunakan}

Metode penelitian yang digunakan dalam penelitian ini adalah research and development ( $\mathrm{R} \& \mathrm{D})$. Sebagai bentuk research and development ( $R$ \& D) [11], maka penelitian tahun pertama dilakukan dengan langkah sebagai berikut:

1. Mengidentifikasi kebutuhan model pembinaan karakter kewargaan multikultural berbasis nilai moral di SMA Negeri 2 Kabupaten Sorong.

2. Memotret pengalaman model pembinaan karakter kewargaan multikultural berbasis nilai moral di SMA Negeri 2 Kabupaten Sorong.

3. Merancang model pembinaan karakter kewargaan multikultural berbasis nilai moral di SMA Negeri 2 Kabupaten Sorong.

4. Memproduksi model pembinaan karakter kewargaan multikultural berbasis nilai moral di SMA Negeri 2 Kabupaten Sorong.

\section{Metode Pengumpulan Data}

Secara umum teknik pengumpulan dan analisis data dibagi menjadi dua kelompok, yaitu studi lapangan dan desk study. Studi lapangan meliputi:

1. Penyebaran angket terhadap kebutuhan pembinaan karakter kewargaan multikultural berbasis nilai moral di SMA Negeri 2 Kabupaten Sorong.

2. Observasi, untuk memperoleh informasi yang terjadi di lapangan.

3. Desk study dalam penelitian ini meliputi:

a. Studi literatur, teknik pemanfaatan data-data sekunder serta data tertulis lainnya mengenai pilar-pilar kebangsaan di Indonesia dan kewargaaan multikultural.

b. Peer Discussion (PD) untuk memperkokoh konstruksi analitik dan teoretik hasil kajian analisis data sementara. c. Focus Group Discussion (FGD) bersama para Guru terhadap temuan kebutuhan pembinaan karakter kewargaan multikultural berbasis pilarpilar kebangsaan di SMA Negeri 2 Kabupaten Sorong.

\section{Teknik Analisi Data}

Analisis data merupakan proses mencari dan menyusun secara sistematis data yang diperoleh dari hasil wawancara, catatan lapangan dan bahan-bahan lain. Dalam penelitian ini teknis analisis data dilakukan secara deskriptif dengan pendekatan data kualitatif [11]. Tahap analisis yang dilakukan adalah.

1. Mengolah dan mempersiapkan data untuk dianalisis.

2. Membaca keseluruhan data

3. Menganalilis lebih detail dengan meng-coding data.

4. Terapkan proses coding untuk mendeskripsikan setting, orang-orang, kategori-kategori dan tematema yang akan dianalisis

5. Tunjukan bagaimana deskripsi dan tema-tema ini akan disajikan kembali dalam narasi/laporan kualitatif

6. Langkah terakhir dalam analisis data adalah menginterpretasi atau memaknai data [12].

Kesimpulan dalam penelitian kualitatif yang diharapkan adalah merupakan temuan baru yang sebelumnya belum pernah ada. Temuan dapat berupa deskripsi atau gambaran suatu obyek yang sebelumnya masih belum jelas, sehingga setelah diteliti menjadi jelas.

\section{HASIL DAN PEMBAHASAN}

\section{Identifikasi karakter kewargaan multikultural yang berbasis nilai moral di SMA Negeri 2 Kabupaten Sorong}

Karakter merupakan perilaku yang lahir dari dalam diri sesorang sehingga perilaku baik dan buruk menunjukkan identitas karakter setiap individu. Karakter kewargaan multikultural dipengaruhi oleh adanya penguatan integrasi nilai-nilai Islam dan kebangsaan ke dalam wajah multikultural pendidikan Islam Indonesia modern perlu dielaborasi lebih lanjut[7]. Lebih lanjut pendapat lain menyatakan bahwa karakter merupakan dapat dibentuk oleh keteladan yang diberikan guru, karena guru sebagai tokoh sentral dalam sekolah sehingga perilaku baik guru akan di ingat oleh siswa mulai kerapian, tutur kata dan pergaulannya. Selain itu juga karakter merupakan perilaku (behaviour), bukan pengetahuan sehingga untuk dapat diinternalisasi oleh peserta didik, maka harus diteladankan bukan hanya diajarkan. Pelaksanaan pendidikan karakter di sekolah lebih tepat melalui pendekatan modeling, keteladanan (uswah) yang dilakukan oleh guru[13].

Menurut Guru sekolah menjelaskan adanya keberagaman karakter siswa,

"Karakter yang dihadapi siswa adalah kesulitan beradaptasi dengan kurikulum dan kultur perguruan tinggi. Ketika kesulitan belajar, mereka takut bertanya, tidak bisa beradaptasi dengan teman/siswa yang beda 
suku, dan hanya berkumpul dengan teman satu suku bahkan hanya berkumpul dengan satu daerah saja. Siswa sangat membutuhkan semacam pembinaan di awal perkuliahan, karena proses adaptasinya terlalu berat bagi pelajar dari Papua yang di darah terpencil".

(Hasil wawancara, 25 Agustus 2018)

Terkait dengan pergaulan, pelajaran yang notabena banyak suku, budaya, ras, dan agama. Bahwa pembinaan karakter kewargaan di perguruan tinggi selama ini telah berjalan namun belum terprogram secara sistemik, sehingga tidak memiliki dampak signifikan.

Menurut guru sekolah menjelaskan adanya degradasi karakter moral siswa dipengaruhi globalisasi, hal tersebut diuraikan bahwa

"Pembinaan karakter di sekolah disamping untuk membendung degradasi karakter kewarganegaraan tetapi kewargaan multikultural, juga berfungsi membentuk karakter Siswa yang kokoh untuk menghadapi aneka tantangan di masa depan, namun yang terjadi justru sebagian siswa yang mengikuti datang sekolah tepat waktu (disiplin), kurang mengerjakan tugas (tidak bertanggungjawab), menjelekkan teman (tidak menghormati)" (Hasil wawancara, 2 6Agustus 2018).

Menurunnya karakter siswa merupakan tanggungjawab semua pihak agar karakter anak tetap tumbuh, jika tidak berikan pembinaan secara kontinu maka karakter anak akan terkikis.

Sementara guru lain menjelaskan ada permasalahan terhadap teman pergaulan. Masalah tersebut diuraikan berikut

"Adanya beberapa permasalahan dalam berbagai kalangan pergaulan Siswa dalam berbagai aspek memberi kesan bahwa perguruan tinggi sedang mengalami krisis etika dan identitas diri. Dalam hal ini, Akademisi menekankan pentingnya pembinaan karakter yang dapat diharapkan menjadi alternatif solusi bagi perbaikan perilaku dan moral". (Hasil wawancara, 25 Agustus 2018)

Upaya mewujudkan karakter Siswa bernilai moral, maka di upaya pembinaan karakter kewargaan terhadap Siswa yang berbeda ras, agama, suku, bahasa dan budaya jadi Sekolah merupakan bagian yang mempunya kewenangan dalam mendidik dan membina Siswa sehingga dapat terbentuk karakter kewargaan yang berbasis nilai moral. Karena SMA Negeri 2 Kabupaten Sorong merupakan perguruan tinggi yang mayoritas jurusan kearah Pendidikan Guru jadi Siswa yang merupakan calon pendidik masa depan dan harus dibentuk model pembinaan baik untuk mahaasiswa maupun siswa yang di ajarkan nanti, jadi model yang di siapkan yaitu model karakter yang berbasis nilai moral dalam lingkungan SMA Negeri 2 Kabupaten Sorong maupun dalam lingkungan kehidupan sehari-hari sehingga Pembinaan karakter ada kesamaan langkah strategis dalam implementasinya.

Hasil penelitian dan pengkajian tim Peneliti PTUPT, terutama beberapa hal yang berkaitan dengan[14]: 1 . Input yang meliputi 4 aspek, yaitu: (a) Landasan Filosofis, (b) Visi \& Misi PT, (c) Isi/Nilai yang dikembangkan, (d) Branding Perguruan Tinggi. 2. Proses yang meliputi 4 aspek, yaitu: (1) Strategi implementasi, (2) Pendekatan Implementasi, (3) Model atau bentuk-bentuk pelaksanaan pendidikan karakter yang sudah dilakukan oleh perguruan tinggi; (4) Program/kegiatan yang dilakukan untuk implementasi pembinaan karakter kewargaan berbasis nilai moral terhadap Siswa SMA Negeri 2 Kabupaten Sorong. 3. Output yang meliputi 3 Aspek, yaitu: (1) Evaluasi Kebutuhan, (2) Rencana Tindak Lanjut dan (3) Evaluasi Model Pembinaan. Pembiaan karakter kewargaan Siswa menjadi intelektual muda bangsa yang memiliki nilai moral sebagaimana tujuan pendidikan nasional.

\section{Kebutuhan Masyarakat Papua dalam Membentuk Karakter Multicultural Berbasis Nilai Moral di SMA Negeri 2 Kabupaten Sorong Papua}

Implementasi pendidikan karakter di sekolah sebaiknya tidak hanya memberikan pengetahuan kognitif, tetapi harus bersifat afektif, konatif, dan ketrampilan. Hal yang perlu diperhatikan pembinaan karakter harus diterapkan pada tiap mata kuliah wajib yaitu pendidikan pancasila dan kewarganegaraan maupun mata kuliah pendidikan Multikultural, sehingga semua pengajar, guru, dan karyawan yang memiliki nilai moral. Dalam penanaman nilai-nilai dan moral agama untuk anak-anak harus pada saat aktivitas kehidupan sehari-hari. Semakin cepat nilai moral ditanamkan kepada anak seperti meletakkan dasar-dasar iman, kepribadian atau karakter yang praktek terpuji dan kebaktian, dalam mengimplementasikannya disesuaikan dengan kemampuan anak[8]. Kebutuhan pendidikan nilai moral di sekolah sangat penting karena dapat memberikan dampak terhadap terwujudnya kewarganegaraan yang baik terutama pada masyarakat multicultural yang di Indonesia.

Menurut psikolog dalam sekolah tersebut menjelaskan

"Dengan situasi demikian maka sangatlah tepat Kementerian Pendidikan memunculkan tema "Pendidikan Karakter" untuk membangun keberadaban bangsa. Pendidikan Karakter telah menjadi agenda besar untuk peradaban bangsa dengan melibatkan semua pemangku kepentingan pendidikan untuk mewujudkannya dengan baik dan benar dalam dunia pendidikan. Untuk itu ada 3 hal utama yang diperhatikan: membekali 
Pendidik yang lintas mata pelajaran/kuliah yang tidak terpisahkan dari profesionalisme guru dan dosen secara berkelanjutan. Pendidikan Karakter sebagai salah satu kegiatan pengembangan diri di perguruan tinggi dan sekolah. Mampu membangkitkan bakat, minat peserta didik dengan suasana yang menarik, dialogis, interaktif dan terbuka. Menciptakan situasi lingkungan yang kondusif sehingga Pembinaan Karakter berbasis nilai moral dapat bersemi dan berakar pada Siswa yang memiliki latar kultur yang berbedabeda." (Hasil Wawncara, 5 September 2018).

Pentingnya pendidikan karakter ditanamkan kepada peserta didik sangat meningkatkan jiwa keteladan yang dikembangkan seorang dengan tujuan karakter nilai moral mereka dapat diamplikasikan dalam kehidupan sehari-hari. Aplikasi dalam kehidupan nyata memiliki kendala-kendala sehingga ilmplementasi nilai karakter tersebut tidak tumbuh dengan baik. Untuk meningkatkan karakter nilai moral anak, perlu di berikan pendidikan khusus berupa karakter mandiri. Pembentukan karakter mandiri seorang santri dalam sebuah lembaga pendidikan, hal ini ditunjukkan dengan adanya kegiatan para santri yang semuanya dikerjakan sendiri tanpa bantuan dari orang tua[15].

Selanjutnya kepala sekolah menjelaskan kebutuhan pendidikan karakter multicultural berbasis nilai moral sangat perlu dikembangkan untuk mewujudkan masyarakat Papua yang multicultural. Menurut Dia menyatakan,

"Dalam kontek ini maka kebutuan terhadap karakter kewargaan Siswa-siswi Papua dan pengembangan kebutuhan pembinaan multikultural dapat dilakukan melalui pembinaan karakter kewargaan multikultural berbasis nilai moral menjadi sangat urgen dan menemukan momentumnya kembali untuk diinteg-rasikan, diperdalam, diperluas dan diselaraskan (sebagai upaya harmonisasi dan sinkronisasi) dalam praksis penguatan karakter kewargaan, budaya sekolah, maupun kehidupan bermasyarakat. Persoalannya adalah bagaimana cara pembinaan, merevitalisasi dan mereaktualisasi nilai-nilai karakter yang dapat diimplementasikan dalam kehidupan seharihari menjadi sebuah kenyataan". (Hasil Wawncara, 5 September 2018)

Karakter anak sangat penting dibina, dibimbing oleh guru karena tujuan utama pendidikan adalah membentuk kepribadian anak yang berakhlak, berilmu, bermoral, beramal, berdisiplin, berbudaya dan bertanggungjawab serta bertoleransi. Karakter-karakter tersebut baru sebagian yang dimiliki oleh siswa-siswa papua, hal tersebut karena kendala letak geografis, alam dan lingkungan serta budaya yang beragam. Hasil penelitian mejelaskan bahwa sekolah sudah berupaya semaksimal mungkin dan sekreatif mungkin dalam menumbuhkan nilai karakter nasionalis di sekolah Papua maupun dengan mengikutsertakan lingkungan di sekitar sekolah Papua lainnya[16]. Sementara karakter akhlak, disiplin, budaya, moral, tanggungjawab dan toleransi cukup baik. Hal tersebut terlihat dengan adanya partisipasi anak sekolah menghadiri upacar bendara, menari, bernyayi sesuai adat dan budaya Papua.

\section{TEMUAN DAN DISKUSI}

Karakter kewargaan multikultural yang berbasis nilai moral merupakan anugerah dari maha pencipta karena telah mampu menciptakan keberagaman agama, budaya, adat istiadat, bahasa, suku dan etnis yang ada dimasyarakat. Terkait dengan karakter yang dihadapi siswa yang terdapat di SMA Negeri 2 Kabupaten Sorong yakni siswa mengalami kesulitan beradaptasi dengan kurikulum dan kultur perguruan tinggi. Ketika kesulitan belajar, mereka takut bertanya, tidak bisa beradaptasi dengan teman/siswa yang beda suku, dan hanya berkumpul dengan teman satu suku bahkan hanya berkumpul dengan satu daearh saja. Namun ada juga siswa yang bisa beradaptasi dengan kurikulum yang ada di sekolah maupun perguruan tinggi. Jadi karakter siswa Papua beragam ada yang aktif da $n$ ada yang pasif. Hasil tersebut sejalan dengan penjelasan bahwa 1) Penumbuhan nilai karakter nasionalis berbasis kelas sesungguhnya sudah ditetapkan dalam kurikulum di sekolah, akan tetapi masih memerlukan kreativitas dari guru lebih lanjut dalam mengimplementasikannya dalam berbagai bentuk kegiatan dalam proses belajar mengajar. 2) Penumbuhan nilai karakter juga dilakukan melalui budaya sekolah. Sebagai upaya lebih lanjut dalam melakukan pembiasaan-pembiasaan yang berbasiskan lingkungan atau komunitas. Melalui program ini penumbuhan nilai karakter nasional didukung oleh nilai-nilai karakter dasar yang dibangun dalam budaya sekolah seperti doa bersama, salam, tepat waktu, disiplin, cinta kepada pahlawan nasional, budaya permintaan maaf jika melakukan kesalahan, budaya terima kasih, dan saling menghormati atau toleransi[16].

Karakter yang dikembangkan siswa di sekolah tersebut adalah karakter:

\section{Disiplin}

Disiplin merupakan peralaku yang mencerminkan ketaatan pada tugas yang berikan dijalankan sesuai dengan waktu. Siswa di Sorong Papua sangat disiplin dalam menjalan tugas sekolahan, baik tugas ekstrakurikuler maupun nontrakurikuler. Ekstra-Kurikuler dan Non-Kurikuler, pada hari sabtu guru PENJASORKES mengajarkan 
kerjasama dan kekompakan dalam melakukan sebuah pekerjaan melalui media olah raga. Tidak hanya itu, guru juga sekaligus menggali nilai-nilai yang bisa diambil dari tokoh-tokoh Papua yang berhasil dalam bidang oleh raga dalam rangka membangkitkan rasa bangga sebagai orang Indonesia[16]. Diperkuat juga oleh penelitian lain menemukan bahwa nilai karakter anak papua dapat dibentuk melalui pendidikan budaya local melalui cerita daerah, pantun, bernyanyi dan melestarikan budaya daerah, karena anak papua akan lebih kreatif, mandiri, tanggung jawab, rasa ingin tahu, kerja keras, disiplin, jujur, religius, toleransi atau saling menghargai, demokratis, menghargai prestasi, peduli lingkungan, teliti, cinta damai, nilai kerjasama atau komunikatif, peduli sosial, semangat kebangsaan dan gemar membaca[17].

Demikian pula penjelasan lainnya menjelaskan bahwa karakter pembentuk kepribadian siswa dapat dilakukan melalui menanamkan rasa cinta terhadap tanah air serta memiliki rasa kebangsaan yang kuat dan dapat membentuk siswa yang dapat menghormati orang dalam kehidupan di sekolah maupun di masyarakat serta mentaati aturan yang berlaku[18].

\section{Tanggungjawab}

Karakter tanggungjawab berperan sebagai factor penguatan pada diri siswa melalui kegiatan bertanggungjawab terhadap tugas sebagai pelajar yang mengedapankan nilai moralitas pada setiap pekerjaan sebagai warga masyarakat, sekolah, lingkungan, bangsa dan Negara sebagai representasi nilai kewargaan yang cinta tanah air. Selain itu, ada sebagian karakter tanggungjawab (responsible) yang dikembangkan dilembaga pendidikan. Karakter tanggung jawab berfungsi sebagai salah satu pilar karakter yang dapat dibangun melalui pendidikan dan implementasinya dalam setiap aspek kehidupan manusia dengan indikator (1) perbuatan yang diharapkan (seharusnya) dilakukan; (2) rencana ke depan; (3) selalu mencoba; (4) selalu melakukan yang terbaik; (5) mengedalikan diri: (6) mendisiplinkan diri; (7) berpikir sebelum bertindakmempertimbangkan konsekuensi; (8) menetapkan contoh yang baik bagi orang lain; dan (9) bertanggung jawab atas kata-kata, sikap, sikap dan tindakan[19].

\section{Menghormati}

Karakter menghormati dan menghargai merupakan perilaku yang selalu dilakukan oleh siswa di SMA Negeri 1 Sorong Papua dalam aktivitas sehari-hari, karena keberagaman siswa cukup variasi yakni ada perbedaan agama, suku, etnis dan bahasa namun dalam implementasinya mereka sangat menghargai perbedaan tersebut. Karena Indonesia merupakan Negara yang multicultural dan memiliki semboyan Bhineka Tungga Ika yang artinya meskipun berbeda tetap satu juang menjadi warga Negara Indonesia. Sejalan juga menurut penelaitian yang menjelaskan karakter menghormati merupakan sikap menghargai diri sendiri, orang lain, dan lingkungan. Hal ini diwujudkan dengan memperlakukan orang lain seperti keinginan untuk dihargai, beradab dan sopan, tidak melecehkan dan menghina orang lain, dan tidak menilai orang lain sebelum mengenalnya dengan baik[20]. Senada juga peneliti lain mengungkapkan menghormati orang lain merupakan nilai dasar yang perlu dikembangkan bagi bangsa Indonesia untuk membangun wawasan global warga negara muda dalam konteks Indonesia antara lain adalah ketuhanan, kemanusiaan, persatuan, kerakyatan dan keadilan social[21]. Jadi konsep pendidikan karakter bagi siswa Sorong Papua Barat mengembangkan karakter disiplin, tanggaungjawab dan menghormati.

\section{E. SIMPULAN DAN SARAN}

Hasil penelitian dapat dikemukakan bahwa sekolah merupakan pihak yang mempunyai kewenangan dalam mendidik dan membina Siswa sehingga dapat terbentuk karakter kewargaan yang berbasis nilai moral. Karena Siswa merupakan calon pendidik masa depan dan harus membentuk model pembinaan berbasis nilai moral dalam lingkungan Siswa di SMA Negeri 2 Kabupaten Sorong. Pembinaan karakter sehingga ada kesamaan langkah strategis dalam implementasinya. Kebutuhan bagi masyarakat multicultural dalam mendidikan anaknya setidaknya mendidik disekolah bervisi karakter building.

Untuk meningkatkan karakter kewargaan multicultural berbasis nilai moral di mahasiswa sebagai penerus generasi penerus sehingga kedepannya terciptanya sumber daya manusia yang berkualitas, yang memiliki derajat keimanan dan ketaqwaan terhadap Tuhan Yang Maha Esa yang tinggi, serta memiliki nilai moral yang dapat digunakan sebagai bekal hidup bermasyarakat dan bernegara, maka sekolah masih perlu melakukan tindakan-tindakan berupa untuk kebutuhan pembinaan karakter kewargaan multicultural SMA Negeri 2 Kabupaten Sorong perlu adanya pembinaan atau kebiasaan sehingga siswa yang berasal dari daerah terpencil atau pedalaman memilki karakter berbasis nilai moral, dan pihak sekolah perlu meningkatkan pembinaan dalam siswa yang berasal dari daerah terpencil di Papua Barat. 


\section{UCAPAN TERIMA KASIH}

Penulis mengucapkan terima kasih kepada Universitas Pendidikan Muhammadiyah Sorong telah mendukung kegiatan penelitian dan SMA Negeri 1 Sorong yang senantiasa memberikan data penelitian dan partner kegiatan kepada penulis sehingga artikel ilimiah ini selesai dengan baik.

\section{DAFTAR RUJUKAN}

[1] I. Ihsan, "Peran Pendidikan Multikultural di Perguruan Tinggi Islam di Papua (Studi Kasus di STKIP Muhammadiyah Sorong Papua Barat)," Citizsh. J. Pancasila dan Kewarganegaraan, vol. 5, no. 1, pp. 24-31, 2017.

[2] J. Miller-Lane, T. C. Howard, and P. E. Halagao, "Civic Multicultural Competence: Searching for Common Ground in Democratic Education," Theory Res. Soc. Educ., vol. 35, no. 4, pp. 551573, 2007.

[3] I. Ihsan, "Kecenderungan Global dalam Proses Pembelajaran Pendidikan Pancasila dan Kewarganegaraan di Sekolah,” JPK (Jurnal Pancasila dan Kewarganegaraan), vol. 2, no. 2, pp. 49-58, 2017.

[4] S. Nasional, "Peraturan Pemerintah Nomor 19 Tahun 2005," Tentang Standar Nas. Pendidik., 2005.

[5] D. Purwanti and M. Nurhayati, "Pengaruh Iklim Organisasi Dan Tipe Kepribadian Terhadap Stres Kerja Dan Perilaku Kewargaan (Studi Pada Karyawan Klinik Laboratorium Prodia Cabang Menteng, Jakarta)," J. Manaj., vol. 20, no. 2, pp. 293-309, 2016.

[6] A. Muwafiq and S. Samsuri, "Pesantren sebagai situs kewarganegaraan dan pembentukan budaya kewargaan di Madura," J. Civ. Media Kaji. Kewarganegaraan, vol. 14, no. 2, pp. 183-195, 2017.

[7] S. Samsuri and M. Marzuki, "Pembentukan Karakter Kewargaan Multikultural dalam Program Kurikuler di Madrasah Aliyah Se-daerah Istimewa YOGYAKARTA," Cakrawala Pendidik., no. 1, 2016.

[8] M. Mubasyaroh, "Model of Religious Study and Moral Values in TK Putra Harapan Nalumsari Jepara," Ta'dib J. Islam. Educ. (Jurnal Pendidik. Islam., vol. 21, no. 2, pp. 191-200, 2016.

[9] I. Z. Adibah, "Pendidikan Multikultural sebagai Wahana Pembentukan Karakter," Madaniyah, vol. 4, no. 2, 2016.

[10] M. Kamal, "Pendidikan Multikultural Bagi Masyarakat Indonesia Yang Majemuk," $\mathrm{Al}-\mathrm{Ta}$ Lim J., vol. 20, no. 3, pp. 451-458, 2013.

[11] J. W. Creswell and J. D. Creswell, Research Design: Qualitative, Quantitative, and Mixed Methods Approaches. Sage publications, 2017.

[12] J. W. Creswell, "Penelitian Kualitatif dan Desain Riset, diterjemahkan oleh Ahmad Lintang Lazuardi," Yogyakarta: Pustaka Pelajar, 2014.

[13] N. Nurchaili, "Membentuk Karakter Siswa melalui Keteladanan Guru," J. Pendidik. dan Kebud., vol. 16, no. 9, pp. 233-244.

[14] A. S. Hidayat, "Manajemen sekolah berbasis karakter," J. Inov. dan Kewirausahaan, vol. 1, no. 1, pp. 8-22, 2012.
[15] D. Setyawan, "Pola Pembentukan Karakter Mandiri Pada Pondok Pesantren Darussalam Mekar Agung Desa Pucanganom, Kecamatan Kebonsari, Kabupaten Madiun Tahun 2015," Citizsh. J. Pancasila dan Kewarganegaraan, vol. 4, no. 1, pp. 354-361, 2015.

[16] A. Bakar and K. Ali, "Nurturing Nationalism Character Values at the Primary Schools in Jayapura, Papua," Cakrawala Pendidik., no. 1, 2018.

[17] M. C. Rumainum, "Nilai Pendidikan Karakter Dalam Cerita Kota Emas Karya Ishak Samuel Kijne," J. Trit. Pendidik., vol. 1, no. 1, pp. 9-18, 2018.

[18] D. Mutmainah and K. Kamaluddin, "Peran Guru Pendidikan Pancasila Dan Kewarganegaraan Dalam Membentuk Sikap Dan Kepribadian Siswa," Civ. Pendidikan-Penelitian-Pengabdian Pendidik. Pancasila dan Kewarganegaraan, vol. 6, no. 2, pp. 44-53, 2019.

[19] P. Siburian, "Penanaman dan implementasi nilai karakter tanggung jawab," J. Gener. Kampus, vol. 5, no. 1, pp. 85-102, 2012.

[20] M. Samani and M. S. Hariyanto, "Konsep dan model pendidikan karakter," Bandung: Remaja Rosdakarya, 2012.

[21] M. Murdiono, "Pendidikan Kewarganegaraan Untuk Membangun Wawasan Global Warga Negara Muda," J. Cakrawala Pendidik., vol. 33, no. 3, 2014 